\title{
Turning Up the Heat: Partisanship in Deliberative Innovation
}

\author{
Carolyn M. Hendriks \\ University of Canberra
}

\author{
John S. Dryzek \\ Australian National University
}

\author{
Christian Hunold \\ Drexel University
}

Two forum types have featured prominently in deliberative practice: (1) forums involving partisans (such as key 'stakeholders') and (2) forums involving non-partisans (such as 'lay citizens'). Drawing on deliberative theory and cases from Germany, we explore the relative merits of these forum types in terms of deliberative capacity, legitimacy and political impact. The two types offer deliberative governance something different. Non-partisan forums such as citizens' juries or consensus conferences rate favorably in deliberative capacity, but can fall short when it comes to external legitimacy and policy impact. Contrary to expectations, partisan forums can also encounter substantial legitimation and impact problems. How can designed forums contribute to deliberative democratization, given that partisanship is an inevitable fact of politics? We offer some suggestions about how deliberative theory and practice might better accommodate the reality of partisanship, while securing benefits revealed in non-partisan forums.

Complex political issues are today often referred to various sorts of advisory forums. Advocates of deliberation might welcome such developments to the extent that they foster more informed and reflective decision-making. But the crucial question is: who then deliberates?

Here we explore the question of who deliberates in terms of partisanship. Politics is fueled by partisans, and indeed exists because of partisanship. Associations, interest groups, activists and organizations share a drive for achieving particular outcomes. Yet their zeal sits uncomfortably with the deliberative ideal that collective political judgement should be a matter of public reasoning. From the perspective of deliberation, partisans make poor deliberators because they have committed agendas (Williams, 2000). Group representatives in particular may lack the autonomy to shift their preferences toward collective interests (Young, 2001). When interests diverge and the stakes are high, partisans are likely to balk at the idea of deliberating with their opponents (Shapiro, 1999), and turn to alternative avenues (Walzer, 1999). Yet from the democratic perspective, partisans are central to deliberative democracy because the legitimacy of decisions rests on their reflective support. Legitimacy in the theory of deliberative democracy exists to the extent that those subject to a collective decision have the right, opportunity and capacity to contribute to deliberation about the decision in question (Benhabib, 1996; Cohen, 1989). Those affected - and certainly those most interested - will often be partisans.

Given that partisanship is an inevitable part of political life, we ask: how can it best be accommodated in deliberative practice? We explore this question by

(c) 2007 The Authors. Journal compilation (C) 2007 Political Studies Association 
comparing two institutional designs that engage partisans in contrary ways. The first model, the partisan forum, involves partisans directly in deliberation. Examples include negotiated rule making (Sunoo and Falkner, 1999), collaborative dialogues (Innes and Booher, 2003), stakeholder search conferences (Pelletier et al., 1999), consensus building and mediation (Susskind et al., 1999). The second design insulates partisans from the forum by placing randomly selected citizens at the centre of deliberations. We label this the non-partisan forum, because ideally the deliberators are 'lay citizens' with relatively open preferences on the issue under discussion. While not necessarily impartial, the participants are nonpartisan to the extent that they are less likely to push a group agenda. In this model, partisans do not deliberate, but are invited to present and defend their position before a panel of citizens. Examples include citizens' juries, consensus conferences, planning cells and deliberative polls (Crosby, 1995; Dienel, 1997; Fishkin, 1995; Klüver, 1995).

Each forum type represents an extreme along a spectrum of partisan engagement. Both are instances of deliberative democracy in action, but only the most incautious advocate would see either as the key to deliberative democratization. They are best thought of as contributions to a larger deliberative public sphere, and in the conclusion we return to the question of how they can contribute in this light.

Currently, little is known about how partisan and non-partisan forum types compare. Archon Fung prefers partisan forums:

hot deliberations with participants who have much at stake make for better deliberation. More participants will be drawn into hot deliberations and they will be more sustainable over time. Participants will invest more of their psychic energy and resources into the process and so make it more thorough and creative. The results of deliberation are more likely to be forcefully supported and implemented (Fung, 2003a, p. 345, emphasis in original).

Partisan forums are also celebrated for their contributions to conflict resolution, interest articulation, democratic schooling and social capital (Fung, 2003b), and their stimulation of broader public deliberation (Mansbridge, 1992). However, many such forums mistakenly assume that those affected by an issue will automatically give voice, thus reinforcing the well-known bias of interest group pluralism to wealthy and well-organized interests. Partisan forums also favor those who claim (often dubiously) to represent a larger group or 'the community' (Carson, 2001; Skocpol, 1999).

Other democrats favor non-partisan forums because they provide more openended deliberative spaces beyond the immediate needs of special interests (Carson and Martin, 1999; Gastil, 2000); participants have no obligations to a constituency and are therefore free to consider arguments on all sides (Dienel, 1997, p. 104). Critics, however, argue that non-partisan forums are employed to bypass experts and elected representatives (Price, 2000) and interest groups (Parkinson, 2004). 
This article will inject some empirical insights into the debate on the relative merits of these two forum models. We do this through in-depth case studies, comparing a partisan and non-partisan forum in terms of their: (1) deliberative capacity; (2) legitimacy; and (3) political impact. Although our focus is on partisanship, we recognize that many other factors influence the operation and legitimacy of deliberative forums. These range from procedural factors such as the numbers of participants, facilitation and selection methods (see Gastil and Levine, 2005; Renn et al., 1995) through to contextual factors such as the kind of issue under deliberation and its socio-political landscape, who commissions and convenes the process and its political relevance (see Button and Mattson, 2000; Newman et al., 2004).

We analyze two deliberative forums from the same country, Germany. Germany has a substantial record of innovation in deliberative forums (see Dienel, 1997; Renn et al., 1995), and a corporatist tradition in which partisanship is recognized but treated as amenable to incorporation into some broader public interest. Both cases centre on the regulation of gene technology: one in food and the other in medicine. While these two applications of gene technology pose slightly different ethical issues, they raise similar kinds of social-technological dilemmas for public deliberation. In both cases the deliberative forum was aimed at providing policy advice and stimulating public debate. Both forums were supported by the relevant ministry. In each forum the participants had access to balanced information, and the discussions were independently facilitated. Our analysis draws on interview data collected by the authors as well as on independent evaluation and assessment reports. ${ }^{1}$

\section{Two Deliberative Cases}

The partisan forum explored here is a national policy dialogue on agricultural gene technology convened by the Green party's Renate Künast, the then German Federal Minister of Consumer Protection, Nutrition and Agriculture. ${ }^{2}$ Between December 2001 and September 2002, thirty interest groups from both sides of the polarized debate participated in a series of stakeholder forums on agricultural gene technology. Participants were selected and invited by the minister, and the groups were represented in the forum by their professional experts and lobbying staff. Participants included representatives from the biotechnology industry, agribusiness, biotechnology research, labor unions, food processors and retailers, farmers' associations, environmental advocacy groups, consumer organizations and Catholic and Protestant churches - all the usual suspects of neo-corporatist policy consultations.

The first phase comprised an opening ceremony on 12 December 2001, the selection of an independent moderator charged with designing and overseeing the policy dialogue, a government hearing on labeling and traceability of genetically modified organisms (GMOs) and the formation of a steering committee, 
with representatives from ten key interest groups and chaired by a representative from the Ministry. A representative from the German Research Foundation and officials from six other federal ministries also attended steering committee meetings.

The second phase involved an introductory conference on the state of gene technology followed by five sessions on issues selected by the participants. The deliberations were prepared and overseen by the steering committee, with the independent moderator acting as its administrative secretariat. Government officials attended the deliberations as observers only; though they did offer their expertise at various stages of the process. Each of the deliberative sessions held between May and July 2002 included public and non-public components. The public sessions comprised seminar-style presentations by invited experts with question-and-answer sessions; these were also open to journalists. In subsequent non-public meetings, interest group representatives then attempted via group discussions to identify areas of agreement and disagreement, with a view to formulating policy recommendations.

The results were made public at a concluding conference on 3 September 2002. They confirmed the depth and persistence of political divisions. The government passed a Gene Technology Act in November 2004, which stipulates protection from GMO contamination for non-GM farmers. If non-GM crops are contaminated in an area where several farmers grow GM crops, they are held jointly and severally liable for damages. The Farmers' Association recommended that farmers should not grow GM crops and should enter into mutually binding voluntary GMO-free contracts as added protection. The Act has been labeled by critics as the 'Gene Technology Prevention Act'.

The non-partisan forum considered here is the national Citizens' Conference (Bürgerkonferenz) on genetic diagnostics held in $2001{ }^{3}$ The issues selected by the citizens for deliberation included genetic diagnostics in health care, preimplantation genetic diagnostics (PGD), pre-natal genetic diagnostics (PND) and stem cell research. ${ }^{4}$ All these technologies pose fundamental challenges in balancing the rights of an individual to bear a 'genetically healthy' child with the need to regulate the technology against potential misuse. At the time of the conference, Germany had no legislation regulating genetic diagnostics, though some technologies were covered indirectly under existing legislation.

The citizens' conference was sponsored by the Federal Ministry of Education and Research with additional support from the German Foundation for Science, and organized by the German Hygiene Museum in Dresden (which covers biological, social and cultural aspects of human life). The project was overseen by a steering committee, whose members were mostly public participation experts. The forum followed the consensus conference model developed in Denmark (Klüver, 1995). It brought together nineteen randomly selected citizens from across Germany to Dresden for three weekends. The first weekend was aimed at 
informing the citizens about the topic and process; the second involved the citizens determining the specific issues for deliberation and selecting presenters from a list prepared by the conveners and an external steering committee. At the actual conference event (the third weekend), interest representatives and experts presented responses to the citizens' questions. After intense deliberation the citizens presented their recommendations to an audience of about 70 people, including a panel of politicians, senior bureaucrats and experts from advisory committees (Schicktanz and Naumann, 2003, p. 63). The report was circulated to approximately 300 people in relevant scientific and political institutions (Schöfer, 2003, p. 300).

With regard to genetic diagnostics in health care, the citizens recommended that the technology should only be available on a voluntary basis and always supported with adequate counseling. They also recommended that genetic data should only be used with the patient's permission by the state, employers or insurance companies. The citizens criticized the expansion of pre-natal genetic diagnostics (PND) and recommended that more information and counseling should be available to women before they undertake any tests. The most surprising outcome was that the majority of the nineteen citizens, including all the women, rejected the introduction of pre-implantation genetic diagnostics (PGD). The majority was also against the use of embryos for stem cell research, but supported similar research on adult cells. ${ }^{5}$

\section{First Comparison: Deliberative Capacity}

Deliberation is a communicative process in which participants are considered equals, open to having their preferences shaped and transformed through reflective public reasoning (Benhabib, 1996; Cohen, 1989). The potential for a forum to reach this ideal is what we label deliberative capacity, ${ }^{6}$ which has at least two aspects: diversity of viewpoints and openness to preference shifts. Diversity ensures that the issue under deliberation is considered from multiple angles. It also reduces the likelihood of enclave deliberation among like-minded people, where views are strengthened rather than questioned (Sunstein, 2002). Openness to preference shift is crucial as deliberators need to be flexible enough to have their perspectives enlarged and even transformed (Gutmann and Thompson, 1996, p. 174).

These two aspects reflect a tension at the heart of deliberative theories. On the one hand, deliberation works best when participants arrive with different viewpoints, while on the other hand it also requires that participants be open to shifting these views.

\section{Diversity of Viewpoints and Partisan Forums}

In a partisan forum, a diverse cross-section of views is typically achieved by ensuring that all relevant positions are present. However, identifying the relevant stakeholders 
will almost always involve some subjective assessment by the forum organizer. Important entities with a potential stake may be excluded simply because their interests extend across conventional political, territorial or generational boundaries. A further challenge to diversity arises when certain groups are unwilling to participate because the forum is likely to expose and unsettle existing power distributions. The 'power-neutralizing' effects of deliberation (Cohen and Rogers, 2003,p.252) may deter partisans. Some theorists believe oppressed and marginalized partisans should shun deliberation that might marginalize them further (Sanders, 1997; Young, 2001), deny their particular needs (Mansbridge, 2003), co-opt them or enmesh them with perceived 'antagonists' and so threaten membership and solidarity (Fung and Wright, 2003, pp. 281-2). Partisans might also be unwilling to participate out of fear of what might be produced. As Robert Goodin has argued (1996, pp. 844-9), deliberation may shift preferences toward more general concerns at the expense of the self-interest of partisans. These concerns remain largely theoretical; arguments can also be made that marginalized groups should benefit from generalizable principles of justice likely to emerge in deliberation (Warren, 2001).

Questionnaires completed prior to the deliberations in our partisan case revealed that relevant interest groups were skeptical that the forum would provide a fair platform for debate (BMVEL, 2002). Their reservations, however, were not related to lack of diversity per se since most accepted that all relevant stakeholders should be included. Of 30 participants, 17 groups favored agricultural gene technology to varying degrees, 12 were opposed and 1 group - the German Housewives' Association-claimed neutrality. The issue had been on the political agenda for about a decade; hence groups with an interest were well known. No invited group refused to participate and there is no evidence that relevant groups were excluded.

The willingness of partisans to take part requires explanation. The cost of boycotting the forum was potentially high. The forum took place at a time when the Ministry was engaged in a campaign to divorce agricultural policy from producer interests, stressing consumer protection, freedom of choice and transparency. But obligations to the European Union (EU) required the government to transpose into national law EU Directive 2001/18/EC (2001), a framework for lifting the existing moratorium on licensing new GM seeds. Even if Germany continued to refrain from planting GM crops, its integration into European and global markets meant that substantial penetration of GM products was likely. High uncertainty meant that both sides hoped to benefit from investing resources in deliberation (compare Cohen and Rogers, 2003, pp. 252-3). Environmental and consumer groups feared an unregulated spread of gene technology through economic integration, while biotech researchers, investors and manufacturers sought a more consistent and enabling regulatory framework.

GM proponents and opponents alike, then, took a strategic view of the forum. Proponents aimed to use the forum to build support for implementing the EU Directive, and to liberalize research and development. Opponents were confident 
that the Green-led Federal Ministry for Consumer Protection, Nutrition and Agriculture would be sympathetic. In our partisan case, diversity of viewpoints was achieved to the extent that stakeholders were willing to participate to pursue their interests.

\section{Diversity of Viewpoints and Non-partisan Forums}

In non-partisan forums there are two dimensions of diversity to consider: first, that of the citizen participants; and second, that of those who present their perspectives to the citizens' panel.

To ensure a diverse panel, participants are selected by lot from a pool of citizens who have expressed interest in participating. Advocates claim that this produces a more diverse set of participants than processes that rely entirely on selfselection because it recruits from 'politically unorganized publics' (see Carson and Martin, 1999). When sample sizes are small, as in the consensus conference or citizens' jury model, stratified random sampling selects for particular characteristics, such as sex, age, locality, education and occupation. All those within each stratum or grouping have an equal chance of being selected. When sample sizes are larger, as in most planning cell projects, 'simple' random sampling ensures diversity (Smith and Wales, 2000, p. 57).

Critics claim that stratified samples can misrepresent the diversity of the population, especially with respect to minority groups (Parkinson, 2006, pp. 78-9). However, in practice the composition of a non-partisan forum is publicly visible, which protects against any major stratification biases. Matters are less straightforward when it comes to political diversity, though demographic diversity promotes attitudinal diversity. ${ }^{7}$

The goal when it comes to presenter diversity is that the citizens should hear all relevant perspectives. The procedure is akin to selection of stakeholders in the partisan forum. However, given that relevant groups and experts are only indirectly engaged in non-partisan forums, securing their commitment is not easy (Hendriks, 2002; 2006). Further, in some designs, such as the consensus conference, the presenters are selected by the citizens from a list of names and organizations prepared by the conveners (Hendriks, 2005; Joss and Durant, 1995). This means that groups and experts are selected on substantive rather than political considerations. For example, citizens might choose to hear from more marginalized groups rather than from more vocal and powerful ones because they are less familiar with their arguments.

The conveners in our non-partisan case had few difficulties attracting diverse participants and presenters. To select the citizens they posted invitations to 10,000 randomly selected people (see Schicktanz and Naumann, 2003). Participants were then randomly selected from the 255 positive responses, which were stratified into 20 groups to fill basic demographic quotas. ${ }^{8}$ Compared against national 
percentages, working people were slightly over-represented, and students and retirees under-represented. The participants held diverse views. Questionnaires completed by participants $(N=19)$ prior to the conference reveal that 8 supported the use of genetic diagnostics, 7 were neutral and 4 against.

The citizens selected sixteen presenters from a list of fifty names. Slightly more presenters with critical views on the technology were selected than proponents. Citizens also chose not to hear from some of the more obvious interest organizations associated with the debate, such as the private health insurance industry. For one of the conveners, this decision was understandable because the citizens wanted to hear from those who were not prominent in the media at the time, such as disability and patient groups (Schicktanz, Interview, Berlin, 2003).

In a partisan forum, diversity relies on identifying and engaging relevant partisans. Securing their commitment is easiest when there are instrumental reasons for partisans to participate. In a non-partisan forum diversity is approached from two angles: (1) randomly selecting participants; and (2) inviting relevant stakeholders to present. We conclude that both forums did an adequate job in encompassing diversity. Now we consider the second aspect of deliberative capacity: openness to preference shift.

\section{Openness to Preference Shift and Partisan Forums}

Partisans normally enter the forum to convince, not be convinced. Deliberation places partisans in a conflict between their representative and deliberative roles (Montpetit et al., 2004). For example, activists in particular can be so caught up in claims of injustice and hardship that they prefer to generate solidarity rather than 'talk to the enemy' about joint interests (Fung and Wright, 2003; Young, 2001). Some studies report that partisans demonstrate few shifts in preferences as a result of participating in deliberation (Pelletier et al., 1999), though as Gerry Mackie (2002) points out, those internally persuaded may find it easier to admit it later, among different participants.

In our partisan case most participants identified the forum's openness of results to preference transformation as a success criterion. Eleven groups pointed to the differentiation of perspectives or the transcendence of existing camps and the achievement of jointly supported results as markers. Expectations here included the generation of mutual understanding and a culture of deliberation. Seven groups defined failure in terms of a further hardening of positions. However, these same participants demonstrated little capacity to shift their own preferences. Both sides stated at the outset their reluctance to endorse outcomes that would compromise their group-specific goals. Statements at the end of the conference confirm the lack of preference transformation:

The initial positions of the participants were and remain well known, and they were and remain very far apart - this remains so following the conclusion of the discourse process (Federation of German Plant Breeders). ${ }^{9}$ 
The German League for Nature Conservation, the peak association of German environmental associations, rejects the use of gene technology in agriculture and food production and nine months of confrontation with the lobbying organizations of the gene technology industry have reinforced this position (German League for Nature Conservation). ${ }^{10}$

Participants acted primarily as delegates rather than trustees, and thus had little autonomy granted by their constituents to shift preferences (Parkinson, 2003, pp. 187-8). Agreement remained limited to uncontroversial goals such as protecting biodiversity, a predictable regulatory environment and freedom of choice. The participants often 'talked about rather than to each other'. ${ }^{11}$ Participants made a serious attempt to reach agreement on a labeling scheme for GM products and for the coexistence of GM and non-GM crops. For some participants, this episode was the high point of the deliberations, although no agreement was reached (BMVEL, 2002, p. 29).

While the partisan participants accepted that deliberation requires willingness to adjust preferences, they failed to translate this into action and held on tightly to their positions. Our case suggests that partisans might be morally committed to the idea of deliberation, but they struggle to put it into practice.

\section{Openness to Preference Shift and Non-partisan Forums}

Non-partisans ought to be more open to reflective preference shift than partisans because they are not pursuing a given agenda, nor are they bound to any constituency. They can more easily consider all sides (Dienel, 1997, p. 104). But critics worry that non-partisans lack the interest and energy necessary for any preference shifts to be reflective (Fung, 2003a, p. 354). Other skeptics are concerned that ordinary people lack the capacity to master complex issues (Price, 2000). Empirical studies find little support for such concerns, and instead report that when lay citizens enter a forum they take their role seriously, eager to learn and discuss issues (see Guston, 1999; Hendriks, 2005; Joss, 1995, pp. 101-4). Many shift their preferences for deliberative reasons (Niemeyer, 2004).

The non-partisan forum case confirmed that citizens demonstrate great capacity to learn about complex matters and to reason together with energy and enthusiasm (Schicktanz and Naumann, 2003, p. 66; Zimmer, 2003). According to the independent evaluator who observed the entire process, the citizens were tolerant and open to different voices, and comments were never personal (Zimmer, 2002, pp. 46-7). Their deliberative capacities were enhanced by the fourteen hours invested over the first preparatory weekend in 'skilling up' (Zimmer, 2002, pp. 18-20).

According to a series of questionnaires conducted at different stages throughout the process, the citizens reported that they had learned much, and most reached clearer positions. Whereas only 16 per cent of the participants rated their 
knowledge on genetic diagnostics as 'high' before the first weekend, this rose to 60 per cent after the final conference (Zimmer,2003,pp.69-70). Their opinions shifted - in most cases towards a more cautionary stance on the technology. No such shifts were observed among a comparable group of citizens who were willing to participate but were not selected in the final random sample. Preference shifts, however, only occurred among those participants who held 'neutral' or undecided preferences prior to deliberation (Zimmer, 2002,pp. 43-5). This suggests that in all deliberative forums - whether partisan or non-partisan - some participants are more partial than others, and it is the most partial who are hardest to move. ${ }^{12}$

To summarize our comparison on deliberative capacity: partisan and non-partisan forums are roughly equal when it comes to encompassing diversity, though in different ways. Non-partisan forums have participants with greater autonomy to change preferences, so their deliberative capacity can be judged superior to that of partisan forums. The core tension between ideals of diversity and openness to persuasion is more readily overcome in non-partisan forums.

\section{Second Comparison: Legitimacy}

Having looked at the deliberative aspects of both forum types, we now consider their democratic dimensions. As pointed out in the introduction, a foundational claim in deliberative democracy is that a procedure and its outcomes are legitimate to the extent that those subject to the decision have the right, opportunity and capacity to participate in deliberation about it. Legitimacy is the 'moral basis of political authority' (Birch, 1993, p. 32). More concretely, it is concerned with why people should consent, and obey the decisions of leaders and institutions. A finite forum cannot feasibly involve all those affected, so legitimacy must be secured in the eyes of non-participants (Parkinson, 2003; 2006). Thus, what happens beyond the forum is as important as what happens inside - such that legitimacy for operational purposes cannot reduce simply to reflective participation on the part of deliberators (as it does in the pure theory of deliberative democracy; see Cohen, 1989). Participants in designed forums generally lack formal principal-agent bonds of the sort familiar in elected representation. Their legitimacy rests instead on descriptive representation. Descriptive representatives are legitimate to the extent that they share key characteristics of their larger group (Mansbridge, 2000; Pitkin, 1967, p. 188).

Legitimacy is not just about who is selected to participate, and how, but also what the forum produces. As John Parkinson (2003, p. 184) points out, legitimacy is shaped by a sense that people consider institutions to be acting in their interests (see also Chambers, 1996). So the advice emerging from different kinds of forum may carry more or less legitimacy depending on how they serve people's interests, and resonate with prevailing discourses. For example, when the dominant policy discourse is shaped by technocratic assumptions, advice from a forum involving experts may carry more legitimacy than a citizens' report. 
For our analysis we operationalize legitimacy as the extent to which key actors, decision-makers and the media accept and support the procedure and its outcomes. While such a subjective definition of legitimacy has its normative limitations (see Beetham, 1991), it is empirically useful because it acknowledges that in practice the ascribed authority (and hence potential impact) of a deliberative forum is strongly influenced by the perceptions of key opinion leaders and the media. In a democracy, the perceptions of mass publics ought to matter as well. But normally the vast majority of the population will be unaware of a forum's existence. Lack of broad public awareness does not necessarily imply lack of legitimacy.

In the following discussion we examine each case in terms of how relevant actors including the media evaluated the respective forum and its outcomes.

\section{Legitimacy and Partisan Forums}

Partisan forums arguably carry more legitimacy because they allow for 'more, not less, participation in agency decisions to the extent that interest groups provide a mechanism for filtering information and pooling resources' (Rossi, 1997, p. 194). The counter-argument is that partisan forums are less legitimate because they represent exclusive corporatist arrangements that exclude everyday perspectives.

In our partisan case there were no problems raised by the key policy actors or the media concerning the forum's composition. In a corporatist system such as Germany, the idea of functional representation of interests is rarely a problem. At the outset, however, several participants voiced concerns about power imbalances. Opponents of agricultural gene technology worried about the biotechnology industry's ability to deploy its superior expertise to dominate debate. Some industry representatives wondered if the government - less than enthusiastic about agricultural gene technology - was truly committed to an open-ended process. ${ }^{13}$ Several groups indicated that they would regard careless simplification and misuse in public of participants' nuanced contributions to the deliberations as a breach of trust. These concerns reflect polarization and mutual suspicion. Yet after the completion of the forum no group identified power imbalances as a shortcoming. In their assessments of the forum, partisans accused one another of being inflexible or wrongheaded, but these comments expressed substantive disagreements rather than concerns about procedural abuses. It is also worth noting that the policy dialogue did not end prematurely as a result of any group(s) walking out on the proceedings in protest, as was the case in an earlier partisan forum on gene technology in Germany (Van den Daele et al., 1997).

Since most of the key actors were also participants, we start by looking at how they assessed the deliberations. Consistent with the observed lack of preference transformation, participants tended to emphasize those outcomes that best supported their goals, and so were selective in granting legitimacy to outcomes. GM 
proponents welcomed the proposed creation of a common stock of knowledge on agricultural gene technology, but complained that opponents continued to ignore 'the science' and experience abroad that found no serious risks. Some proponents believed the deliberations had given too much time to the question of whether to employ agricultural gene technology at all, rather than to more practical questions of how its use might be regulated. Consider the following comment made by the German Research Association and the Umbrella Organization of Agriculture, Forestry, Nutrition, Veterinary, and Environmental Science Associations: ${ }^{14}$

We are under the impression that the selection of issues for discussion was based primarily on group interests and less on overriding, rationally justified criteria.... The fact that several groups continue to propagate, full steam ahead, the German path of a zero option shows that facts are being ignored or that there is a need for further information.

GM opponents, for their part, criticized proponents for prematurely trying to force the issue in light of the alleged logic of international trade. Opponents emphasized the limits of scientific knowledge, with church groups trying to carve out space for ethical argument on the technology's risks and benefits. Particularly for gene technology proponents, legitimacy was strongly linked to an understanding of scientific knowledge as objective, accurate and certain. For them a forum is a fact-finding process that should reveal universal truths. This attitude may have been facilitated by the German context, where techno-rational approaches to policy-making are common (Stark, 2001).

Media reports were generally skeptical, taking the government to task for letting participants get away with restating well-known positions. The forums were also reported as business as usual: when the government cannot or does not want to decide, it sets up yet another round table. One pro-industry commentator dismissed the deliberations as a 'marathon of meetings' (Beyreuther, 2004). A journalist from the middle-of-the-road weekly Die Zeit accused the government of hiding behind the deliberations to avoid taking a position before the 2002 elections (Boeing, 2002). In the conservative daily Frankfurter Allgemeine Zeitung, a commentator was similarly unimpressed and suggested the polemical emphasis on vague generalities would not generate useful advice (Haas, 2002).

To summarize, our partisan forum had no perceived legitimacy problems in its composition, moderate problems in media acceptance of its existence and substantial problems in stakeholder acceptance of outcomes.

\section{Legitimacy and Non-partisan Forums}

Substantial legitimacy issues were raised in the Dresden citizens' conference. Interviews with key policy actors (who in this case remained largely outside the forum) indicate that the legitimacy of the citizens' deliberations and report was 
questioned, especially on epistemic grounds. Human geneticists and scientific advisers were skeptical about the capacities of lay citizens (interviews, Dresden and Berlin, 2003). They also raised concerns about the potential for manipulation via the selection of experts, the personalities of speakers or via the group dynamics within the citizens' panel. In particular, the citizens' selection of the presenters was criticized on the basis that the citizens chose to hear disproportionately from groups opposing genetic diagnostics. According to the evaluator (Zimmer, 2002, p. 23), critics declared that 'It's no wonder that the citizens produced the outcomes they did'.

Those not selected were upset. As one interest representative expressed, 'how could a deliberative process on genetic diagnostics be taken seriously when it excluded the views of the private insurance industry?' (interview, Munich, 2003). To compensate for not being able to present at the conference, private insurance groups tried to bring their perspectives into the discussions by raising issues as members of the conference audience (Newman, interview, Dresden, 2003). Other elite policy actors interviewed stressed that the citizens' conference should not be given greater status than other expert forums, or the views of families affected by genetic disorders. A number of geneticists belittled the citizens' report for not contributing any new arguments (interviews, Berlin, 2003).

Weaker interests, such as patient and disability groups as well as anti-gene technology groups, were more positive about the forum and welcomed the opportunity to contribute to the debate. However, they did raise concerns about the capacity of 'abled' and healthy people to appreciate their arguments. In effect they believed the panel lacked the appropriate 'politics of presence' (Phillips, 1995). But in the end very few interviewees disputed the legitimacy of the citizens' report.

The media generally accepted the legitimacy of the citizens' conference. The forum was reported in 32 articles in German daily newspapers, one television segment and four radio programs (Zimmer, 2002, pp. 49-52). The forum took place at a time when there was rising public debate over the dominance of experts and elites in controversial technology issues. This was especially the case for genetic diagnostics, which had been delegated to a plethora of expert committees producing contrary recommendations. Journalists took hold of these contrasting positions, drawing attention to the subjectivity of expert advice and questioning the legitimacy of committees composed of hand-picked experts. Against this background the citizens' conference was a breath of fresh air, welcomed by the media.

Factoring in the more positive media response, the non-partisan forum performed somewhat better on legitimacy than the partisan forum. Legitimacy in the partisan case turned largely on whether the deliberations produced the preferred outcome for the organizations with an interest in the case. This is of course a purely instrumental standard, its persistence itself representing a delib- 
erative shortcoming. The legitimacy of our non-partisan case appears to have rested more on procedural matters such as the mode of participant selection. Epistemic concerns were also central. Some questioned the legitimacy of the citizens' forum on the grounds that the participants did not adequately comprehend 'the science', or appreciate what it was like to be 'affected'.

\section{Third Comparison: Impact}

The impacts of any deliberative process can be multiple and diverse. They include changes to substantive policy content, the reframing of issues, effects on public discourse more generally and shifts in the attitudes of elites and publics (Goodin and Dryzek, 2006). Isolating and empirically measuring these impacts can be problematic, especially given their diffuse and temporally dispersed character (O’Neil, 2003; Rowe and Frewer, 2000).

\section{Impact and Partisan Forums}

The agricultural gene technology deliberations produced little jointly supported policy advice. The subsequent Gene Technology Act was consistent with the governing coalition's prior policy privileging non-GM farmers over biotechnology companies and scientists. Minister Künast cited persistent public opposition to agricultural gene technology in defense of the government's restrictive implementation of the deliberate release directive (Sentker and Schuh, 2004). Unable to achieve an outright ban at EU level, the government obstructed and delayed the technology. That the stakeholder deliberations largely confirmed the preexisting stalemate on agricultural gene technology policy did not encourage the government to change course.

Although the forum produced no policy agreement, it yielded a greater sense of what divides opponents and proponents of the technology. The government interpreted the persistence of deep disagreements revealed by the forum as backing its position that GMOs should be commercialized very carefully and with high levels of protection for non-GM farming. The revelation of diverse perspectives and their attendant justifications is itself a form of policy advice: proceed with great caution.

The deliberations also had little overt effect on stakeholders' preferences or the world views shaping them. Consider the following comments made by Greenpeace and an industry coalition after the deliberations:

The discourse on green gene technology failed to achieve any real progress from the perspective of Greenpeace. To be sure there was much debate ... But the commercial interests of the biotechnology and seed industry got in the way of [the search for] consensus. ... Growing GM crops must be prevented. ${ }^{15}$

The coalition 'From the Farm to the Fork' believes the coexistence of GM production methods and non-GM production methods is possible and necessary. 
The coexistence and mutual complementarity of these different systems guarantees the diversity of products desired by the consumer. ${ }^{16}$

Both quotes highlight the reluctance of each side of the debate to approach a consensus on whether, and under what conditions, the technology might reasonably coexist with other methods of production.

What impact did the deliberations have on broader public discourse? Records were published on a website. The documentation included dates of events, presentations of invited experts, summary reports and minutes of deliberations, and press releases. In their opening statements, eight groups stated that they hoped the deliberations would provide the public and policy-makers with detailed information and facilitate opinion formation. Simply publishing information on the Web, however, represents a one-way model of communication between citizens and government that falls well short of empowered participation (Fung, 2004). The other main avenue of publicity was via the media, whose skeptical coverage we have already noted. Thus the forum was not well placed to have substantial impact on broad public discourse.

\section{Impact and Non-partisan Forums}

Citizens' reports from non-partisan forums are typically advisory, and their recommendations thus compete with inputs from policy analysts, expert committees and interest groups. When these other sources recommend the same policies and celebrate the same values articulated in the citizens' reports, it can be difficult to determine which source holds more sway.

The impact of the citizens' conference was evaluated independently by the Fraunhofer Institute (Zimmer, 2002, pp. 55-8). The evaluation concluded that impact on subsequent policy activities was limited by competing debates and reports from several expert advisory committees and parliamentary commissions, which produced contradictory recommendations. However, as we noted earlier, the citizens' recommendations were treated by the media as a fresh perspective in a landscape cluttered with competing expert opinions.

Several policy actors reported that they found the conference valuable (Hendriks, 2004, pp. 169-99). Some were impressed by the competence and level of engagement of the citizens, and were proud to have been part of Germany's first national consensus conference. None of the 24 actors interviewed believed that the process had altered the way they understood the issue, or that it had changed their relationships with other actors in the debate. Yet, as one optimistic official put it (Interview, Berlin, 2003), 'The conference process did not bring any new points into the discussion but it brought new weights to things - you have to say this'.

The modest direct policy impact of this particular non-partisan forum is consistent with reports concerning many other such forums. However, cases can be 
found of more direct impact; for example, the 'Dialogue with the City' on urban planning in Perth, Australia, whose recommendations have been incorporated into the planning strategy of the Western Australian state government (Carson and Hartz-Karp, 2005, pp. 132-4).

In short: the impact of both forum types we have examined was limited, though contrary to expectations the partisan case did not perform any better.

\section{Conclusion}

When we began this research we conjectured that partisan forums would more readily achieve impact and legitimacy, because they involve key actors in a position to obstruct impact and deny legitimacy; they would share 'ownership' of the process. We also hypothesized that non-partisan forums would have greater capacity to achieve quality deliberation. While the latter expectation has been borne out, the former has not. Our non-partisan case was clearly superior in terms of deliberative capacity. And though it had clear shortcomings in terms of impact and legitimacy, it performed no worse and in some aspects better than the partisan forum. The challenge then becomes one of securing the high deliberative capacity that non-partisan forums can deliver while correcting for any shortcomings in legitimacy and impact. Simply moving to the partisan end of the spectrum does not necessarily help; in the case we looked at, the partisan forum actually exhibited less in the way of legitimacy, and about the same in impact. Thus Fung's (2003a) claims for the efficacy of making deliberation 'hot' (quoted at the outset) are not borne out in our comparisons.

Of course these findings are colored by the specifics of our two German cases, and these themes might well play out differently for other issues and political contexts. Drawing on their work in the United States of America, Judith Innes and David Booher (2003, pp. 39-42) claim that partisans are more likely to engage in dialogue when they are diverse and interdependent - and have the capacity to hurt one another. Partisans will also freely enter deliberative forums if the alternative is either a costly stalemate or continuing high risk to all sides. In other words, there must be a mutually unsatisfactory status quo. Paradoxically, the presence of dysfunctional representative and legal institutions might then facilitate partisan deliberation in designed forums. This perhaps explains the success of mediation and consensus-building approaches to policy conflict resolution in the United States (Susskind et al., 1999), where widespread access to veto power, especially through the courts, makes costly stalemate common. This consideration also suggests that Germany might not offer quite the hospitable environment for deliberative forums as would appear at first sight. Institutional designers should be sensitive to this kind of issue: it is not enough simply to design a forum and send out invitations, no matter how good the design seems to be. Partisans need some incentive to deliberate, and that will initially be a matter of their instrumental calculation (see Hendriks, 2006). 
From the point of view of deliberative ideals, there remains something unsatisfactory about pinning the legitimacy of any agreement on instrumental calculation by partisans. It is more unsatisfactory still to pin legitimacy on whether the forum delivered the desired outcome from the point of view of any given actor-an attitude that characterized some of the actors in our partisan case.Legitimacy in a more robust sense would exist to the extent that outcomes are accepted by partisans who disagree with them. Often this disagreement will be a matter of degree, for rarely does a partisan deliberative forum rule unequivocally against one of its participants.

How can we secure high-quality deliberation, given that partisanship is an inherent part of political life? Here we offer three suggestions presented in ascending degrees of feasibility.

The first would involve constitutionalizing non-partisan deliberation. This is, for example, the program proposed by Ethan J. Leib (2004) in his suggested addition of a fourth deliberative branch of government in the United States, composed of citizens' panels. Thoroughly utopian in the American context, its prospects might be somewhat better in political systems less resistant to participatory innovation. Less ambitiously, John Gastil (2000) and Ned Crosby suggest linking nonpartisan forums to existing electoral processes. ${ }^{17}$

The second would have partisans deliberate alongside non-partisans on equal terms. We have seen that ostensibly non-partisan forums do in fact feature participants with different degrees of partiality; for although none of the participants actually represents an interest, some inevitably have strong views about the issue before the forum commences, while others have not previously formed any views. So incorporating partisans more systematically would in a sense simply extend an existing feature of non-partisan forums; though how to do this without the partisans setting the agenda and dominating discussion (because they are experienced activists) would be a major design challenge. Some steps in this direction have been made recently in Australia, where hybrid deliberative innovations have been applied which incorporate partisan and non-partisan procedures (see Carson and Hartz-Karp, 2005). ${ }^{18}$ The challenge here is not only one of institutional design: partisans and non-partisans need to be engaged and participate as equals. To facilitate more equal participation marginalized groups and citizens may need additional material resources, and conventional notions of representation and 'valid' knowledge will need to be reconsidered.

The third suggestion would see both kinds of forum as moments in the life of a larger public sphere, so resonating with conceptions of deliberative democracy that emphasize these diffuse public processes as opposed to formal settings. Fung (2003a) speaks of deliberative forums as 'recipes for public spheres', but it may be better to think of them as 'recipes within public spheres'. This solution entails ratcheting down expectations concerning legitimacy - even an intervention into public debates widely regarded as illegitimate can have an impact (just as social movements can). It also necessitates seeing impact, not in terms of influence on 
public policy, but in terms of affecting the engagement of discourses in the public sphere. Democratic theories that emphasize the public sphere welcome it conditionally, recognizing that it can also be home to demagoguery, sensationalism, spin, public relations and commercialization of the media (see for example Dryzek, 2000). Many of these shortcomings are the results of the machinations of partisans; non-partisan forums could help provide a corrective.

Building a more deliberative democracy is not easy. There is no magic bullet for securing the advances of deliberative quality that can be achieved in non-partisan forums, while taking care of the tough challenges posed by legitimacy and impact questions that arise in a world of partisans. Designed forums can play a role in deliberative democratization, but they are never going to be the whole story. Deliberative democratization must itself be a deliberative process, as opposed to the application of some standard set of institutional designs.

(Accepted: 27 September 2006)

\section{About the Authors}

Carolyn M. Hendriks, School of Business and Government, University of Canberra, ACT 2601, Australia; email: carolyn.hendriks@canberra.edu.au

John S. Dryzek, Social and Political Theory Program and Political Science Program, Research School of Social Sciences, Australian National University, Canberra, ACT 0200, Australia; email: j.dryzek@ coombs.anu.edu.au

Christian Hunold, Department of History and Politics, Drexel University, Philadelphia, PA 19104, USA; email: hunoldc@drexel.edu

\section{Notes}

We would like to thank Bob Goodin and three anonymous reviewers for their comments.

1 Given the small sample of cases analyzed our intention is not to produce the definitive statement on partisan and non-partisan forums. Instead we study two cases in detail to expose some of the more subtle effects of partisanship on deliberative institutions.

2 For details, see BMVEL (2003).

3 For details, see Schicktanz and Naumann (2003).

4 Pre-natal genetic diagnostics (PND) is used in the early stages of pregnancy to determine whether an embryo has any genetic conditions representative of detectable diseases. Pre-implantation genetic diagnostics (PGD) is used to determine the genetic condition of artificially developed 4-8-cell embryos (eggs fertilized in vitro) before they are implanted.

5 For more details, see the online report at http://www.buergerkonferenz.de/index_2000.php

6 Deliberative capacity refers to the potential to achieve deliberative ideals, rather than the actual quality of the deliberation. On the latter, Steiner et al. (2004) have developed a discourse quality index that measures a debate in terms of standards derived from Habermas' communicative ethics. The index has proven useful in assessing parliamentary debates, but it is limited to cases where debate has been recorded and transcribed, and where the volume of discussion is well defined; it is also silent on preference transformation.

7 In rare cases, samples are stratified on the basis of attitudinal positions on the issue under deliberation (e.g. Crosby, 1995).

8 In the end one of the twenty citizens selected could not attend, resulting in nineteen participants.

9 Federation of German Plant Breeders, 'Chance zur Vielfalt nutzen - Koexistenz der Produktionsverfahren im Pflanzenbau', Bonn, 2002. 
10 German League for Nature Conservation, 'Gentechnikfreiheit sichern, Wahlfreiheit gewährleisten', 2 September 2002. Available at http://www.bund-brandenburg.de/dokus/gentechnik_stellungnahme\%20diskurs\% 20 gentechnik\%20bmvel.pdf

11 Professor Wolfgang van den Daele, quoted in Boeing (2002).

12 We rely heavily here on Zimmer's evaluation of the process, which we acknowledge was sponsored by the organizers. However, based on our interview with Zimmer (Karlsruhe, 4 February 2003) and after listening to the tapes of the process and studying the questionnaires, we find his evaluation to be thorough and independent.

13 Minister Künast reaffirmed this commitment in the opening ceremony.

14 German Research Association and Umbrella Organization of Agricultural, Forestry, Nutrition, Veterinary, and Environmental Science Associations, 'Stellungnahme zum Diskurs "Grüne Gentechnik", .

15 Henning Strodthoff, 'Gesellschaft vor Entscheidung: Agrarwende oder Gentech-Landwirtschaft?’. Bewertung des Künast-Diskurses zur Grünen Gentechnik, 16 October 2002.

16 Warenkette vom Acker bis zum Teller, 'Vielfalt fördern - Innovationspotenzial wahren'. Thesenpapier zur Grünen Gentechnik, October 2002.

17 Ned Crosby and Pat Benn have been working on a Citizen Initiative Review, where a group of citizens deliberate to inform voters on the projected costs and expected benefits of pending citizens' initiatives. See http:// www.cirwa.org

18 Hybrid deliberative designs have also been run in Germany (see Renn et al., 1993).

\section{References}

Beetham, D. (1991) The Legitimation of Power. Basingstoke: Macmillan.

Benhabib, S. (1996) 'Toward a Deliberative Model of Democratic Legitimacy', in S. Benhabib (ed.), Democracy and Difference: Contesting Boundaries of the Political. Princeton NJ: Princeton University Press, pp. 67-94.

Beyreuther, K. (2004) 'Das Gentechnik-Gesetz in seiner jetzigen Form bedeutet eine Verhinderung der Grünen Gentechnik in Deutschland [The Gene Technology Act in its Current Form Means a Hindrance to Green Gene Technology in Germany]', Frankfurter Allgemeine Zeitung, 10 November.

Birch, A. H. (1993) The Concepts and Theories of Modern Democracy. London: Routledge.

BMVEL (2002) Diskurs Grüne Gentechnik: Ergebnisbericht. Berlin: Bundesministerium für Verbraucherschutz, Ernährung und Landwirtschaft. [Discourse on Green Gene Technology: Outcomes Report. Federal Department of Consumer Protection, Nutrition and Agriculture.] Available from: http://www.transgen.de/pdf/diskurs/ ergebnisbericht.pdf [Accessed 1 December 2004].

BMVEL (2003) Diskurs Grüne Gentechnik. Hintergründe, Standpunkte und Erwartungen zum Einsatz der Gentechnik in der Land- und Ernährungswirtschaft. Berlin: Bundesministerium für Verbraucherschutz, Ernährung und Landwirtschaft. [Discourse on Green Gene Technology: Background, Perspectives and Expectations Concerning the Use of Gene Technology in Agriculture and the Nutrition Industry. Federal Department of Consumer Protection, Nutrition and Agriculture.]

Boeing, N. (2002) 'Gut, dass wir geredet haben [Good that We've Talked]', Die Zeit, 5 September. Available from: http://www.zeit.de/archiv/2002/37/200237_glosse.xml [Accessed 1 December 2004].

Button, M. and Mattson, K. (2000) 'Deliberative Democracy in Practice: Challenges and Prospects for Civic Deliberation', Polity, 31 (4), 609-37.

Carson, L. (2001) 'Innovative Consultation Processes and the Changing Role of Activism', Third Sector Review, 7 (1), 7-22.

Carson, L. and Hartz-Karp, J. (2005) 'Adapting and Combining Deliberative Designs', in J. Gastil and P. Levine (eds), The Deliberative Democracy Handbook: Strategies for Effective Civic Engagement in the Twenty-First Century. San Francisco CA: Jossey Bass, pp. 120-38.

Carson, L. and Martin, B. (1999) Random Selection in Politics. Westport CT: Praeger Publishers.

Chambers, S. (1996) Reasonable Democracy: Jürgen Habermas and the Politics of Discourse. Ithaca NY: Cornell University Press.

Cohen, J. (1989) 'Deliberation and Democratic Legitimacy', in A. Hamlin and P. Pettit (eds), The Good Polity: Normative Analysis of the State. Oxford: Basil Blackwell, pp. 17-34.

Cohen, J. and Rogers, J. (2003) 'Power and Reason', in A. Fung and E. O. Wright (eds), Deepening Democracy: Institutional Innovation in Empowered Participatory Governance. London: Verso, pp. 237-55. 
Crosby, N. (1995) ‘Citizens Juries: One Solution for Difficult Environmental Problems', in O. Renn, T. Webler and P. Wiedemann (eds), Fairness and Competence in Citizen Participation. Dordrecht: Kluwer, pp. 157-74.

Dienel, P. C. (1997) Die Planungszelle. Eine Alternative zur Establishment-Demokratie. [The Planning Cells. An Alternative to Establishment-Democracy], fourth edition with Status Report '97. Opladen: WestdeutscherVerlag.

Dryzek, J. S. (2000) Deliberative Democracy and Beyond: Liberals, Critics, Contestations. Oxford: Oxford University Press.

EU Directive 2001/18/EC (2001) 'Directive 2001/18/EC of The European Parliament and of the Council of 12 March 2001on the Deliberate Release into the Environment of Genetically Modified Organisms and repealing Council Directive 90/220/EEC'. Available from: http://europa.eu.int/eur-lex/pri/en/oj/dat/ 2001/1_106/1_10620010417en00010038.pdf [Accessed 4 December 2004].

Federation of German Plant Breeders (2002) 'Chance zur Vielfalt nutzen - Koexistenz der Produktionsverfahren im Pflanzenbau’, Federation of German Plant Breeders, Bonn.

Fishkin, J. (1995) The Voice of the People: Public Opinion and Democracy. New Haven CT: Yale University Press.

Fung, A. (2003a) 'Survey Article: Recipes for Public Spheres: Eight Institutional Design Choices and Their Consequences', Journal of Political Philosophy, 11 (3), 338-67.

Fung, A. (2003b) 'Associations and Democracy', Annual Review of Sociology, 29, 515-39.

Fung, A. (2004) Empowered Participation. Princeton NJ: Princeton University Press.

Fung, A. and Wright, E. O. (2003) 'Countervailing Power in Empowered Participatory Governance', in A. Fung and E. O. Wright (eds), Deepening Democracy: Institutional Innovation in Empowered Participatory Governance. London: Verso, pp. 259-89.

Gastil, J. (2000) By Popular Demand: Revitalizing Representative Democracy through Deliberative Elections. Berkeley CA: University of California Press.

Gastil, J. and Levine, P. (eds) (2005) The Deliberative Democracy Handbook: Strategies for Effective Civic Engagement in the Tiventy-First Century. San Francisco CA: Jossey-Bass.

Goodin, R. E. (1996) 'Enfranchising the Earth, and Its Alternatives', Political Studies, 44 (5), 835-49.

Goodin, R. E. and Dryzek, J. S. (2006) 'Deliberative Impacts: The Macro-political Uptake of Mini-publics', Politics and Society, 34 (2), 219-44.

Guston, D. H. (1999) 'Evaluating the First US Consensus Conference: The Impact of the Citizens' Panel on Telecommunications and the Future of Democracy', Science, Technology E Human Values, 24 (4), 451-82.

Gutmann, A. and Thompson, D. (1996) Democracy and Disagreement. Cambridge MA: Belknap.

Haas, L. (2002) 'Diskurs Grüne Gentechnik: erste Klausurtagung [Discourse on Green Gene Technology: First Workshop]', Frankfurter Allgemeine Zeitung, 17 May, 48.

Hendriks, C. M. (2002) 'Institutions of Deliberative Democratic Processes and Interest Groups: Roles, Tensions and Incentives', Australian Journal of Public Administration, 61 (1), 64-75.

Hendriks, C. M. (2004) Public Deliberation and Interest Organisations: A Study of Responses to Lay Citizen Engagement in Public Policy. Unpublished PhD thesis, The Australian National University, Canberra.

Hendriks, C. M. (2005) ‘Consensus Conferences and Planning Cells: Lay Citizen Deliberations', in J. Gastil and P. Levine (eds), The Deliberative Democracy Handbook: Strategies for Effective Civic Engagement in the Twenty-First Century. San Francisco CA: Jossey Bass, pp. 80-110.

Hendriks, C. M. (2006) 'When the Forum Meets Interest Politics: Strategic Uses of Public Deliberation', Politics and Society, 34 (4), 571-602.

Innes, J. E. and Booher, D. E. (2003) 'Collaborative Policymaking: Governance through Dialogue', in M. Hajer and H. Wagenaar (eds), Deliberative Policy Analysis: Understanding Governance in the Network Society. Cambridge: Cambridge University Press, pp. 33-59.

Joss, S. (1995) 'Evaluating Consensus Conferences: Necessity or Luxury?', in S. Joss and J. Durant (eds), Public Participation in Science: The Role of Consensus Conferences in Europe. London: Science Museum, pp. 89-108.

Joss, S. and Durant, J. (eds) (1995) Public Participation in Science: The Role of Consensus Conferences in Europe. London: Science Museum.

Klüver, L. (1995) 'Consensus Conferences at the Danish Board of Technology', in S. Joss and J. Durant (eds), Public Participation in Science: The Role of Consensus Conferences in Europe. London: Science Museum, pp. 41-9. 
Leib, E. J. (2004) Deliberative Democracy in America: A Proposal for a Popular Branch of Government. University Park IL: Pennsylvania State University Press.

Mackie, G. (2002) 'Does Democratic Deliberation Change Minds?'. Paper presented at Workshop on Democratic Theory, The Australian National University, Canberra.

Mansbridge, J. (1992) 'A Deliberative Theory of Interest Representation', in M. P. Petracca (ed.), The Politics of Interests. Boulder CO: Westview Press, pp. 32-57.

Mansbridge, J. (2000) 'What Does a Representative Do? Descriptive Representation in Communicative Settings of Distrust, Uncrystallized Interests, and Historically Denigrated Status', in W. Kymlicka and W. Norman (eds), Citizenship in Diverse Societies. Oxford: Oxford University Press, pp. 99-123.

Mansbridge, J. (2003) 'Practice-Thought-Practice', in A. Fung and E. O. Wright (eds), Deepening Democracy: Institutional Innovation in Empowered Participatory Governance. London: Verso, pp. 175-99.

Montpetit, E., Scala, F. and Fortier, I. (2004) 'The Paradox of Deliberative Democracy: The National Action Committee on the Status of Women and Canada's Policy on Reproductive Technology', Policy Sciences, 37 (2), 137-57.

Newman, J., Barnes, M. and Sullivan, H. (2004) 'Public Participation and Collaborative Governance', Journal of Social Policy, 33 (2), 203-23.

Niemeyer, S. (2004) 'Deliberation in the Wilderness: Displacing Symbolic Politics', Environmental Politics, 13 (2), $347-72$.

O’Neill, C. (2003) 'Understanding the Impact of Participation in a Deliberative Forum', in J. Font (ed.), Public Participation and Local Governance. Barcelona: Institut de Ciéncies Polítiques i Socials, pp. 201-24.

Parkinson, J. (2003) 'Legitimacy Problems in Deliberative Democracy', Political Studies, 51 (1), 180-96.

Parkinson, J. (2004) 'Why Deliberate? The Encounter between Deliberation and New Public Managers', Public Administration, 82 (2), 377-95.

Parkinson, J. (2006) Deliberation in the Real World: Problems of Legitimacy in Deliberative Democracy. Oxford: Oxford University Press.

Pelletier, D., Kraak, V., McCullum, C., Uusitalo, U. and Rich, R. (1999) 'The Shaping of Collective Values through Deliberative Democracy: An Empirical Study from New York's North Country', Policy Sciences, 32 (2), 103-31.

Phillips, A. (1995) The Politics of Presence. Oxford: Clarendon Press.

Pitkin, H. F. (1967) The Concept of Representation. Berkeley CA: University of California Press.

Price, D. (2000) ‘Choices without Reasons: Citizens' Juries and Policy Evaluation', Journal of Medical Ethics, 26 (4), 272-6.

Renn, O., Webler, T., Rakel, H., Dienel, P. C. and Johnson, B. (1993) 'Public Participation in Decision Making: A Three-Step Procedure', Policy Sciences, 26 (3), 189-214.

Renn, O., Webler, T. and Wiedemann, P. (eds) (1995) Fairness and Competence in Citizen Participation. Dordrecht: Kluwer.

Rossi, J. (1997) 'Participation Run Amok: The Costs of Mass Participation for Deliberative Agency Decisionmaking', Northwestern University Law Review, 92 (1), 173-249.

Rowe, G. and Frewer, L. (2000) 'Public Participation Methods: A Framework for Evaluation', Science, Technology E Human Values, 25 (1), 3-29.

Sanders, L. M. (1997) 'Against Deliberation', Political Theory, 25 (3), 347-76.

Schicktanz, S. and Naumann, J. (2003) 'Ablauf und Methode - die erste bundesweite Bürgerkonferenz [Procedure and Method - The First Nation Wide Citizens' Conference]', in S. Schicktanz and J. Naumann (eds), Bürgerkonferenz: Streitfall Gendiagnostik [Citizens' Conference: Conflict over Genetic Diagnostics]. Opladen: Leske + Budrich, pp. 57-68.

Schöfer, J. (2003) Partizipative Technikfolgenabschatzung und politische Entscheidungen. [Participatory Technology Assessment and Political Decisions]. Dipolma Arbeit [Unpublished Master's thesis], Institut für Politische Wissenschaft, Universität Hamburg, Hamburg.

Sentker, A. and Schuh, H. (2004) 'Billige Stimmungsmache [ Cheap Shots]', Die Zeit, 16 September. Available from: http://www.zeit.de/2004/39/K_9fnast_Gespr_8ach [Accessed 1 December 2004].

Shapiro, I. (1999) 'Enough of Deliberation: Politics is about Interests and Power', in S. Macedo (ed.), Deliberative Politics. Oxford: Oxford University Press, pp. 28-38. 
Skocpol, T. (1999) 'Associations Without Members', The American Prospect, 45 (July-August), 66-73.

Smith, G. and Wales, C. (2000) 'Citizens' Juries and Deliberative Democracy', Political Studies, 48 (1), 51-65.

Stark, C. (2001) 'Germany: Rule by Virtue of Knowledge', in R. Münch, C. Lahusen, M. Kurth, C. Borgards, C. Stark and C. Jauß (eds), Democracy at Work: A Comparative Sociology of Environmental Regulation in the United Kingdom, France, Germany and the United States. Westport CT: Praeger Publishers, pp. 103-28.

Steiner, J., Bächtiger, A., Spörndli, M. and Steenbergeren, M. R. (2004) Deliberative Politics in Action: A Cross-National Study of Parliamentary Debates. Cambridge: Cambridge University Press.

Sunoo, J. J. and Falkner, J. A. (1999) 'Regulatory Negotiations: The Native American Experience', in L. Susskind, S. McKearnan and J. Thomas-Larmer (eds), The Consensus Building Handbook. Thousand Oaks CA: Sage Publications, pp. 901-22.

Sunstein, C. (2002) 'The Law of Group Polarization', Journal of Political Philosophy, 10 (2), 175-95.

Susskind, L., McKearnan, S. and Thomas-Larmer, J. (1999) The Consensus Building Handbook. Thousand Oaks CA: Sage Publications.

Van den Daele, W., Pühler, A. and Sukopp, H. (1997) Transgenic Herbicide-Resistant Crops. A Participatory Technology Assessment. Summary Report. Discussion Paper FS II 97-302. Berlin: Wissenschaftszentrum Berlin für Sozialforschung.

Walzer, M. (1999) 'Deliberation, and What Else?', in S. Macedo (ed.), Deliberative Politics. Oxford: Oxford University Press, pp. 58-69.

Warren, M. E. (2001) Democracy and Association. Princeton NJ: Princeton University Press.

Williams, M. S. (2000) 'The Uneasy Alliance of Group Representation and Deliberative Democracy', in W. Kymlicka and W. Norman (eds), Citizenship in Diverse Societies. Oxford: Oxford University Press, pp. 124-52.

Young, I. M. (2001) 'Activist Challenges to Deliberative Democracy', Political Theory, 29 (5), 670-90.

Zimmer, R. (2002) Begleitende Evaluation der Bürgerkonferenz 'Streitfall Gendiagnostik' [Accompanying Evaluation of the Citizens' Conference 'Conflict over Genetic Diagnostics']. Karlsruhe: Fraunhofer-Institut für Systemtechnik und Innovationsforschung.

Zimmer, R. (2003) 'Phasen des Meinungsbildungprozesses - Ergebnisse der begleitenden Evaluation [Phases in the Opinion Formation Process - Results from the Accompanying Evaluation]', in S. Schicktanz and J. Naumann (eds), Bürgerkonferenz: Streitfall Gendiagnostik [Citizens' Conference: Conflict over Genetic Diagnostics]. Opladen: Leske + Budrich, pp. 67-78. 